\title{
A Curator's Viewpoint
}

\author{
Rick Darke \\ Longwood Gardens, Kennett Square, PA 19348-0501
}

Longwood Gardens, Inc., is a not-for-profit display garden open to the public, with $\approx 800,000$ visitors per year. The plant collections are comprised of $>11,000$ taxa, and the majority of plants in public display areas have labels providing common name, scientific name, and cultivar if applicable.

My responsibilities include the identification, naming, and labeling of all plants at the gardens. Determination of species names of plants is a straightforward undertaking in most cases. Identification and nomenclatural verification of cultivars that make up nearly $60 \%$ of our new accessions are much more problematic. This work is rapidly becoming more difficult as a result of the recent practice of using trademark names. Unless some compromise is reached, this practice will undermine the basis of our system of horticultural nomenclature. An understanding of the problem requires knowledge of the horticultural code and patent and trademark regulations.

The International Code of Nomenclature for Cultivated Plants [ICNCP] (Brickell, 1980) is produced and updated periodically by the International Commission for the Nomenclature of Cultivated Plants of the International Union for Biological Sciences. Having no force of law, the code is essentially a "gentleman's agreement", the primary aim of which is "to promote uniformity, accuracy, and fixity in the naming of agricultural, horticultural, and silvicultural cultivars (varieties). .." [article 3]. The code also states: "Each cultivar has one correct cultivar name, the single name by which it is internationally known" [article 35]; "Registration of cultivar (variety) names is of the greatest importance for nomenclatural stability" [article 4]; "Registration is the acceptance of a cultivar name by a cultivar registration authority and the inclusion of this name in a register" [article 53]; and "A cultivar name must be freely available for use by any person to denote the cultivar (variety) whose name it is. A cultivar name cannot, in general, be registered as a trademark" [article 3]. Since 1 Jan. 1959, cultivar names must be "fancy names", not botanical names in Latin form [article 27], and should not be "composed of abbreviations, numerals or arbitrary sequences of letters. .." [recommendation 31A]. Although these are all commendable goals, on a worldwide basis they are often impractical and ignored.
Our awakening to the trademark dilemma began in 1984, with the receipt of a number of new patented hollies. The label on each plant contained two names; a "fancy" name in single quotes, followed by an apparent code name in parentheses. Examples of the labels attached to the plants included 'Blue Maid' (variety Mesid), 'Blue Stallion' (variety Mesan), 'China Girl' (variety Mesog), 'China Boy' (variety Mesdob), and 'Dragon Lady' (variety Meschick). After receiving no explanation from the nursery, we wrote to the Registrar of the International Registration Authority for hollies for advice on which names constituted cultivar names. After noting that the names in parenthesis (e.g., Mesid, Mesan) appear on the patent applications, the Registrar replied "As far as I'm concerned these designations or whatever they are have no nomenclatural status. I have recognized only what appear to be the suitable cultivar names 'Blue Maid', 'Blue Stallion', etc." We accessioned and labelled the plants accordingly, ignoring the parenthetical names. We have since learned that the names we ignored (e.g., Mesid, Mesan) were actually the cultivar (variety) names, and that the fancy names were trademarks.

We were not the only ones confused. The above trademark names have erroneously been represented as cultivars in a number of recent professional articles and references, including Dirr (1983) in his widely used Manual of Woody Landscape Plants, Andrews (1988) in her article "The Blue Hollies", in The Royal Horticultural Society's The Garden, and Orton (1986) in an article "The Blue Hollies" in The Holly Society Journal, to cite a few. This confusion is a result of a marketing strategy that is increasingly being adopted by commercial nurseries and other introducers of new plants.

Patents and trademarks are regulated in the United States by the Patent and Trademark Office of the Dept. of Commerce. A federal plant patent gives the applicant the right to exclude others from propagating the plant in question for 17 years (U.S. Dept. of Commerce, 1986). Applicants generally must state the common name of the plant when applying. For legal purposes, the "common" name is equivalent to the "generic" name (meaning "general", not referring to the botanical genus). It also is equivalent to the "variety" name (again in the general sense, not the botanical var- 
ietas), and is therefore equivalent to the "cultivar" name. Patents are nonrenewable, and once the patent expires, anyone is free to propagate the plant in question.

A trademark "may be a word, symbol, design or combination word and design, a slogan or even a distinctive sound which identifies and distinguishes the goods or services of one party from those of another", and unlike a copyright or patent, "trademark rights can last indefinitely if the mark continues to perform a sourceindicating function." Also, unlike a patent, a trademark need not be registered formally; trademark rights arise from proper use of the mark. Owners of unregistered marks use a ${ }^{\mathrm{TM}}$ symbol to indicate a claim of ownership. Registration offers further legal advantages and also allows the owner to use the ${ }^{\circledR}$ symbol. Ownership of a trademark does not give you any right to exclude others from propagating your plant introduction; rather, it grants you the right to sue anyone who attempts to use your trademark.

The above definition makes clear that a trademark must not be the name of the product itself, but rather an adjective indicating origin. You might buy Kleenex ${ }^{\varpi}$ brand facial tissues because you believe the Kleenex ${ }^{\circledast}$ company to manufacture a superior product. The trademark in this case properly indicates origin, not a particular type, size, or color of facial tissues. If you refer to the product itself as kleenex, the name is not functioning as a mark of origin but as a generic name for facial tissues. Such use can invalidate the mark, as has happened with former trademark names like escalator and linoleum.

The use of trademark names is not new to the nursery business. For example, The Conard-Pyle Co. owns the Star ${ }^{\circledast}$ mark. For many years, the company has correctly used this mark to indicate origin, such as in catalog references to Star ${ }^{\circledast}$ roses. A Star rose is not any particular cultivar but is one of the many roses produced by The Conard-Pyle Co. Monrovia Nursery's distinctive black and yellow label is another good use of a trademark, in this case a symbol, to indicate origin. The problem arises when trademark names are made to appear synonymous with the individual cultivar names of plants. For example, the owners of the registered trademark China Girl ${ }^{\circledR}$ have legal right to use it in association with any plants they produce, to indicate origin. However, the mark has consistently appeared in catalogs only in association with the patented holly cultivar 'Mesog', and, until recently, the mark appeared in single quotes, a typographical device usually used in horticultural literature to denote cultivar name. Since the patent on 'Mesog' is still in effect, its propagation is restricted. The intention is that by the time the patent expires, buyers will only be familiar with the name China Girl $^{\circledast}$, which will still be the sole property of the owners of the mark. Therefore, although anyone at that time will legally be free to propagate 'Mesog', they will not be able to sell it as China Girl ${ }^{\varpi}$ without infringing the mark. Such use seems contrary to the intent of trademark law, since the mark is not being used to indicate origin. Additionally, there is nothing to prevent the owners of the mark from applying it to a different cultivar of holly if they wish. Since according to both trademark regulations and the ICNCP, a trademark is not fixed to any particular cultivar, a scientific paper that unwittingly refers to germplasm only by a trademark name has actually failed to make permanent reference to the germplasm. For example, Pemberton et al. (1988) refer to their germplasm as 'Orange Sunblaze' and 'Lady Sunblaze', when in fact these names are not cultivars but registered trademarks. The trademark office is not responsible for policing the use of trademarks, and although it is possible to mount a legal challenge to a registered trademark, such action is often prohibitively expensive.

A second trend involving trademarks is just as worrisome as the preceding, and involves the trademarking of names that were previously well-established cultivar names. For example, Acer rubrum 'October Glory' and Tilia cordata 'Greenspire' are two well-known street trees. Both cultivars were patented in 1961 (\#2116 and \#2086, respectively) and recognized as common names by the American Assn. of Nurserymen (1963). These names have been published as cultivars in major horticultural references such as Dirr (1983), Flint (1983), and Clarke (1988). However, advertisements by the original patent owners now claim that these two names are not cultivars but trademarks, and in fact the owners did apply for and receive U.S. federal trademark registration for October Glory and Greenspire in 1974. The owner of the marks now contends that the cultivar names for these two plants are 'PNI0268' and 'PNI6025', respectively.

A third situation results from the lack of any system of crosschecks between cultivar registrars and the trademark office. Understandably, few registrars of International Registration Authorities are equipped to make world-wide searches of trademark registrations before registration of new cultivars. This can lead to registration of cultivar names that may infringe on existing trademarks in one or more countries. Similarly, the U.S. Patent and Trademark Office is not equipped to make a thorough worldwide check of all existing cultivars of all plants before approving registration of a new trademark. The office generally checks applications only against the list of existing U.S. trademarks. This can lead to registration of trademarks that are in conflict with existing historic and registered cultivars.

There will probably be no simple solution to these dilemmas. At the moment, the proponents of trademarks and those who cling to the existing nomenclatural code appear to be in two opposing camps. It seems clear, however, that it is best for all concerned to reach some compromise that will satisfy both interests. We all need a system that will provide adequate protection for the rights of the developers and marketers of new plants, while preserving order and stability in nomenclature.

\section{Literature Cited}

American Assn. of Nurserymen. 1963. Directory of plant patents with common names. Amer. Assn. Nurserymen, Washington, D.C.

Andrews, S. 1988. The blue hollies. J. Royal Hort. Soc. 113(1):43-45.

Brickell, C. (ed.). 1980. International code of nomenclature for cultivated plants-1980. W. Junk, The Hague, Netherlands.

Clarke, D. 1988. Supplement to W.J. bean trees and shrubs hardy in the British Isles. John Murray, London.

Dirr, M. 1983. Manual of woody landscape plants. 3rd ed. Stipes Publishing, Champaign, Ill.

Flint, H. 1983. Landscape plants for eastern North America. Wiley, New York.

Orton, E. 1986. The blue hollies. J. Holly Soc. 4:(3):7,8.

Pemberton, H.B., J.W. Kelly, and M.L. Struthers. 1988. The effects of temperature and storage time during simulated shipping on miniature pot roses. ASHS/CSHS 1988 Annu. Mtg., East Lansing, Mich., Prog. \& Abstr. HortScience 23(3):729[73].

U.S. Dept. of Commerce. 1986. General information concerning patents. U.S. Dept. Commerce, Patent \& Trademark Office, Washington, D.C. p. 2. 